\title{
THE IMPACT OF CORPORATE GOVERNANCE PRACTICES ON POST-MERGER PERFORMANCE ${ }^{*}$
}

\section{KURUMSAL YÖNETIMM UYGULAMALARININ BİRLEŞME SONRASI PERFORMANSA ETKISİ}

\author{
Ali İhsan AKGÜN ${ }^{1}$
}

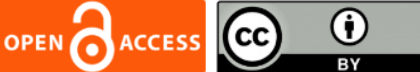

1. Prof. Dr., Ankara Yıldırım Beyazıt University, Department of Health Management, ihsan.akgun@ybu.edu.tr, https://orcid.org/0000-0002-6441-8196

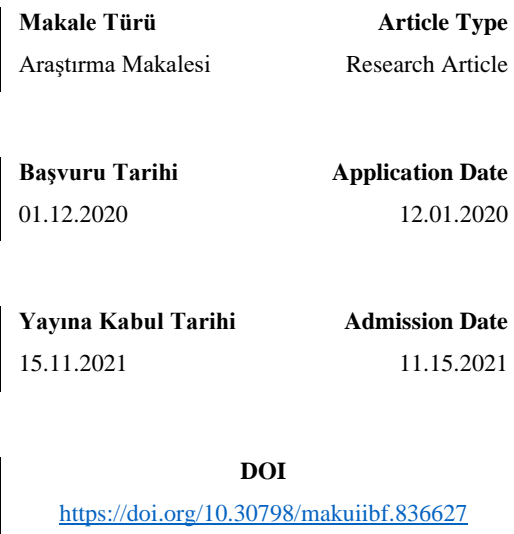

\footnotetext{
This study is supported by the Scientific and Technological Research Council of Turkey (TUBITAK) reference number (B.14.2.TBT.0.06.01219-84).
}

\begin{abstract}
The relation between the post-merger performance and corporate governance mechanism is examined using Linear regression model for a sample of US, Canada, EU28 and Western European countries listed firms for the period from 2003 to 2012 . We also examine as to whether the use of International Financial Reporting Standards (IFRS) improves corporate transparency, therefore, increasing financial reporting quality. Using a sample of banks from international countries, we present the following key findings: post-merger performance is significantly better common law in countries than code law in countries with better IFRS group banks during the post-merger performance. We also find that local GAAP reporting allows a more transparent assessment of financial performance on the basis of traditional indicators making it a superior tool for assessing potential acquisition targets. This study analysis changes in a country legal regulation as a measure of corporate governance and shows that these regulations play an important role in merger activity. Legal origins and owner-protection mechanisms are important in explaining the relationship between the quality of accounting standards and corporate governance practices following IFRS adoption. Overall, our empirical findings result consistent with Ciobanu (2015) find that merger and acquisition is influenced both the legal origin and accounting regulations.
\end{abstract}

Keywords: Corporate Governance Practices, Post-Merger Performance, Legal Origin, IFRS.

Öz

Kurumsal yönetim mekanizması ile birleşme sonrası performans arasındaki ilișki, 2003 2012 dönemine ait ABD, Kanada, AB-28 ve Batı Avrupa ülkelerinin borsaya kayıtlı firmalarından oluşan örneklem için Doğrusal Regresyon modeli kullanılarak incelenmiștir. Uluslararası Finansal Raporlama Standartlarının (IFRS) kullanılması kurumsal şeffaflığı ve dolayısıyla finansal raporlamanın da kalitesini artırır. Bu çalışma, uluslararası banka örneklemini kullanarak, așağıdaki temel bulguları sunmaktadır: Birleşme sonrası bankaların performansı, IFRS grubu bankaların kanun esaslı hukuk sistemini benimseyen ülkelerden daha iyi göstergede olduğunu göstermektedir. Ayrica, yerel GAAP raporlamasının, geleneksel hukuk sistemini benimseyen göstergeler temelinde finansal performansın daha şeffaf bir şekilde değerlendirilmesine olanak tanıdığını ve potansiyel hedeflerini değerlendirmek için üstün araç olduğunu göstermektedir. Bu çalışmanın bulguları, kurumsal yönetişimin bir ölçüsü olarak bir ülke yasal düzenlemesinde farklılık gösterdiğini ve bu düzenlemelerin birleșme faaliyetinde önemli bir rol oynadığını göstermektedir. Yasal düzenlemeler ve mal sahipliğine yönelik kurumsal yönetim mekanizmaları, IFRS'nin zorunlu uygulamasından sonra muhasebe standartları ile kurumsal yönetim uygulamaları arasındaki ilişkiyi açıklamada önemlidir. Genel olarak, araştırma bulgularımız Ciobanu (2015)'nin sonuçları ile tutarlı olup, birleşme ve devralmanın hem yasal menşei hemde muhasebe düzenlemelerini etkilemiștir

Anahtar Kelimeler: Kurumsal Yönetim Uygulamaları, Birleşme Sonrası Performans, Yasal Düzenlemeler, IFRS. 


\section{Çalışmanın Amacı}

\section{GENIŞLETILMIŞ ÖZET}

Sınır ötesi birleşme ve devralmalar (M\&As), muhasebe ve finans literatüründe önemli bir husus olarak kabul edilmektedir. Mevcut literatür, M\&As'lerin yatırımcıların korunma kalitesini belirleme potansiyeline sahip olduğunu göstermiştir (La Porta vd, 1998; Rossi ve Volpin, 2004). Dünyadaki yasal düzenlemeler ve banka düzenlemeleri kurumsal yönetim mekanizmasında önemli bir rol oynamaktadır. Daha da önemlisi, güçlü yasal düzenlemeler ve katı piyasa düzenlemeleri, farklı finansal raporlama sistemlerine sahip ülkeler arasında birleşme ve satın alma işlemleri gerçekleştirerek farklı ülke bankalarının etkin bir şekilde faaliyet göstermesine yol açabilir. Bu çalışma, farklı ülkelerin yasal düzenlemeleri ve banka düzenleme kuralları arasındaki farkları göz önüne alarak, yasal düzenlemeler ve piyasa düzenleyici kuralının birleşme sonrası banka performansında önemli bir rol oynadığını göstermiştir. $\mathrm{Bu}$ çalışmanın amacı, kurumsal yönetimin bir ölçüsü olarak, bir ülke yasal düzenlemesindeki farklılıkların banka birleşmesi sonrasındaki performansında önemli rol oynayıp oynamadığını ortaya koymaktır. Muhasebe standartlarına yönelik yasal düzenlemeler ve mal sahipliği koruma mekanızmaları, Uluslararası Finansal Raporlama Standartları (IFRS)'nin zorunlu uygulamasından sonra muhasebe standartlarının kalitesi ile kurumsal yönetim uygulamaları arasındaki ilişkiyi açıklamada önem arzetmektedir. Ayrıca, bu çalışma, finansal raporlama uygulamalarında IFRS' in kullanımının kurumsal şeffaflığı artırdığını, dolayısıyla finansal raporlamanın kalitesini artırıp artırmadığını da incelemektedir. Bu çalışmada, birleşen 246 bankanın yerel genel kabul görmüş muhasebe standartları (GAAP) veya IFRS kullanmasının banka performans1 ve kontrol grubu bankaların performansı karşılaştırılarak analiz edilmiştir. Çalışmamız literatüre iki farklı katkı sağlamaktadır. İlk olarak bir ülkenin yasal düzenlemelerinin kurumsal yönetim uygulamaları olan finansal raporlama setini nasıl etkilediği, ikincisi ise, ülke düzeyinde yasal düzenlemelerin birleşen bankaların denetçi ücretlerini nasıl etkilediğidir.

\section{Araştırma Soruları}

Birleşme ve satın almalar (M\&As), günümüzün küreselleşen iş sürecinde çok önemli bir büyüme ve stratejik gelişme aracı olmaya devam etmektedir. Bununla birlikte, birleşme ve satın alma faaliyetinin bu popülaritesi bazı güçlükleri beraberinde getirmiştir, çünkü birçok ampirik çalışma, bu anlaşmaların çoğunun beklentileri karşılayamadığını ve hatta satın alanlar için mevcut firma değerini bile düşürdügünü göstermektedir. Bu nedenle, birleşme ve devralmalar, farklı ülkelerden firmaların farklı ekonomik, kurumsal ve yasal sistemlere sahip olması nedeniyle finansal piyasalar arasındaki farklılıklardan dolayı güçlükler içermektedir. $\mathrm{Bu}$ bağlamda, bu çalışmada; kurumsal yönetim uygulamalarının birleşme sonrası performansa etkisi var mı? sorusu önemli bir araştırma sorusu olarak karşımıza çıkmaktadır. 


\section{Literatür Araştırması}

Çoğu ülke ekonomisinde, M\&A özel yasaların yönetilmesinde önemli bir rol oynamaktadır. $\mathrm{Bu}$ nedenle, hükümetler, ulusal ekonomilerini genişletmek ve kurumsal performansı artırmak ve böylece kurumsal performansı iyileştirmek için uygun rekabet ortamlarını sürdürmek için M\&A yasalarını revise etmişlerdir. Banka birleşmeleri gerek ulusal ve gereksede uluslararası çalışmalara konu olmuştur. Marshall ve Anderson (2009), yasal düzenleme arttıkça hedef şirket getirilerinin ve devir primlerinin daha yüksek olduğunu belirtmişlerdir. Anderson vd. (2009) 'un bulguları, güçlü yatırımcı koruma ortamlarında, işletme performansı ile kurumsal yönetim uygulamaları arasında negatif bir ilişki olduğunu göstermektedir. Ciobanu (2015) çalışmasına göre, birleşme ve satın alma işleminin sadece yasal kökeninden değil, aynı zamanda şirketlerin faaliyetlerini yöneten düzenlemelerden de etkilendiğini öne sürmektedir.

\section{Yöntem}

$\mathrm{Bu}$ çalışmanın veri seti, $\mathrm{M} \& \mathrm{~A}$ işlemlerine yönelik olarak Thomson One Banker M\&A ve Bankscope data kaynağındaki M\&A işlemlerinde kullanmak üzere bankaların bilanço ve gelir tablosu verileri birleştirilerek elde edilmiştir. Örneklem dönemi, 01/01/2002 ile 31/12/2012 tarihleri arasında ilan edilen M\&A işlemlerini içermektedir. Örnekleme ait dönem, her ülkenin kendi yerel GAAP veya IFRS standartları setine göre hazırlanan yıllık raporlama döneminden oluşmaktadır. Söz konusu bu dönem, Avrupa Birliği tarafından 19 Temmuz 2002 tarihinde onaylanan uluslararası muhasebe standartlarının tüm firmalar için 2005 tarihinden itibaren zorunlu olarak uygulanması için yönetmeliğin gereklerini yerine getirmeye başladığı dönem arasında geçen süre olduğu için seçilmiştir. Kurumsal yönetim uygulamaları ile banka birleşmesi sonrası performans arasındaki ilişkiyi analiz etmek için, Doğrusal Regresyon Modeli (Zakarı vd., 2017), aşağıda belirtildiği gibi kullanılmıştır: Post-merger financial performance $=\beta 0+$ B1AccountingStandardsit $+\beta 2$ LegalOriginit $+\beta 3$ AuditFeesit $+\beta 4$ sizeit + eit Burada,bağımlı değişkenler; sermaye yapısı (eta), varlık yapısı (nlta), fon yapısıs (llrl), maliyet etkinliği (cir), gelir yapısı (niexpa) ve karlılık (roa) açısından banka performansının geleneksel göstergeleridir. Bağımsız değişkenler ise, birleşme sonrası dönemdeki kurumsal yönetim uygulamalarıdır. Ayrıca, kontrol değişkeni olarak da banka büyüklüğü için bankaların toplam varlıklarının logaritması kullanılmıştır.

\section{Sonuç ve Değerlendirme}

$\mathrm{Bu}$ çalışmada, kurumsal yönetim uygulamalarının, birleşmelerden kaynaklanan banka performansı üzerindeki etkisi incelenmiştir. Genel olarak, bulgularımız, teklif veren bankanın banka performansı birleşme sonrası performansını etkilediği ve ayrıca, kurumsal yönetim uygulamalarından finansal raporlama standartlarının ve ülkedeki yasal düzenleme farklılıklarından etkilendiğini göstermektedir. 


\section{INTRODUCTION}

Corporate governance mechanisms influence to accounting and financial reporting practices (Anderson et al., 2004). More importantly, good corporate governance practices suggest that a company should ensure timely and accurate disclosure is made on all material matters (Munisi and Randøy, 2013). The more detailed, accurate and reliable financial reports is the information disclosed by a company, the better will be the public perception of the firm's value and shares (Barako et al., 2006). Thus, disclosure can be more important to attract investors for financial information users. La Porta et al. (2000) suggest that the quality of accounting standards play a critical role in corporate governance, in particular, bring information to the investor. In this context, the country-level legal origins may be affect corporate governance on banking firms' accounting standards choices. Role of accounting standards in corporate governance mechanism provide the information needed to measure the business performance (Drever et al., 2007). As a result, accounting information is an important component of corporate governance and has key roles to control actions of firms and management decisions and to inform shareholders. In the present research, we add to the literature by providing shed light on the investigating the relationship between corporate governance practices and the post-merger bank performance.

Corporate governance practices differ from across countries and within countries, also across companies. This corporate governance differences impact firm valuation and performance in crossborder mergers and acquisition. Starks and Wei (2013) used some alternative proxies for the level of governance in the foreign bidder countries: an indicator for whether the country is an indicator for the country's legal origin, a shareholder rights measure, and a measure of the quality of accounting disclosures in the country. They find that growing with better corporate governance practices in that their use binary measures to represent whether the country has better or worse corporate governance. From these proxy's countries' legal origin plays a crucial important role in explaining link between accounting standards quality and corporate governance practices after International Financial Reporting Standards (IFRS) adoption. In other words, regulation provide strong incentives for high quality financial reports after the introduction of IFRS. Our proxy result evidence that provide evidence consistent with hypotheses advanced in the corporate governance literature, by motivating La Porta et al. (1997, 1998, 2000, 2008), Starks and Wei (2013), Leuz et al. (2003) and Hope (2003a). There is a recent frame of literature that efforts to understand why and how a country's legal origin affects the country's institutions, and how legal origin and institutions, distress economic and financial outcomes (La Porta et al., 2008; Allen et al., 2005).

We examine the effectiveness of the legal origin proxies in what should be a comparatively important framework. This framework is the relationship between the accounting standards and the firm's information environment, as reflected in bank merger performance. In this context, corporate governance practices may affect by the legal origin under the accounting standards within the bank post- 
merger performance. These study focus on the most widespread legal system including common law and code law under local Generally Accepted Accounting Principles (GAAP) or IFRS, as implemented in US, Canada, EU-28 and Western European countries. We assume that bank post-merger performance is affected not only by the accounting standards as a corporate governance mechanism but also by institutional factor such as legal system. We examine the relationship between bank merger performance and corporate governance practices across US, Canada, EU-28 and Western European countries from 2002 to 2012, finding that corporate governance affected in countries with stronger legal system.

In sum, our results suggest that, with respect to corporate governance and relative to proxies for legal origin more generally, the recently published both La Porta et al. (2006), Brown et al. (2014) and Preiato et al. (2015) measures of accounting standards practice capture important differences between our bank merger samples countries' information environments such as legal origin proxies. More importantly, Preiato et al. (2015) suggest that accounting standards practice can be more significant and more general effects legal origin proxies for corporate governance enforcement. Similarly, our paper adds to a growing body of empirical findings that legal origins are more important than accounting standards in determining the quality of accounting numbers (Ball et al., 2000; Ball et al., 2003), within the corporate governance using bank merger sample.

Mergers and acquisitions (M\&As) has continued to be a crucially important means of growth and strategic development in today's globalizing business process. This popularity of M\&A activity is somewhat challenges, however, since numerous empirical evidence suggests that the majority of these deals fail to live up to expectations and often even destroy value for acquirers (Zakaria et al., 2017). Thus, M\&As involve unique challenges due to the differences between the financial markets since firms from different countries have different economic, institutional and legal system. In this context, this study appears an important research questions: does impact of corporate governance practices on the post-merger performance?

This study analysis changes in a country legal regulation as a measure of corporate governance and shows that these regulations play an important role in merger activity. Legal origins and ownerprotection mechanisms are important in explaining the relationship between the quality of accounting standards and corporate governance practices following IFRS adoption. Overall, our empirical findings result consistent with Ciobanu (2015) find that M\&A activities is influenced both the legal origin and accounting regulations. We also examine as to whether the use of IFRS improves corporate transparency, therefore, increasing financial reporting quality. This is attempted by comparing the performance of merged 246 banks in which the target and acquirer banks employed the same reporting system-IFRS or local GAAP-to the performance of a control group of banks not engaged in M\&A activity. 
Our study creates two following contributions. First, we contribute to the literature of how a country's legal origin affect corporate governance mechanisms such as financial reporting incentives (Kuo and Lee, 2018). Second, our study notifies the debate concerning how country-level legal regimes affect auditor fees. Our study adds to these studies by suggesting that common law legal system can substitute the governance functions of auditors fees as it reduces the audit risk from financial reporting applications by consistent with the argument of Choi and Wong (2007).

The remainder of this study progresses as follows. Next section describes the related literature and hypotheses development. Section 3 describes the research design, methodology and data used in the study. Section 4 presents the empirical results and Section 5 concludes the study.

\section{RELATED LITERATURE AND HYPOTHESES DEVELOPMENT}

\subsection{Related Literature}

According to European Comminitues (EC) Directives, the use of IFRS aims is to provide the comparability and transparency of financial statements and also to improve the quality of financial reporting. However, the effectiveness of IFRS adoption may be vulnerable by differences across countries, in the institutional and legal setting in which financial reporting occurs. Therefore, our paper of outcomes from adopting IFRS uses a range of legal origin proxies to capture across the different countries. A large number of literatures explore the effects of adoption of IFRS in the global financial markets. For example, numerous studies suggest that the use for enforcement accounting standards may differ between countries for institutional differences (Pope and McLeay, 2011). Daske et al. (2008) suggest that enforcement and governance regimes including specific initiatives relating to enforcement of accounting standards where legal enforcement is strong. Recent studies have used a variety of metrics to capture key elements of the institutional setting, including legal system origin and attributes of the legal setting that proxy for investor protection (La Porta et al., 1998). Recent studies have also considered enforcement changes by strong legal and regulatory systems to promote compliance with accounting standards (Brown et al., 2014; Christensen et al., 2013; Hitz et al., 2012).

Legal origin is an important factor for the role of countries culture and the most crucial important from an accounting research perspective. Although legal origin is a key determinant of disclosure levels, Hope (2003a) find that its importance decreases with the richness of a firm's information environment. Moreover, the governance transparency factor is primarily related to a country's legal origin. For example, Bushman et al. (2004) findings show that governance transparency is higher in countries with a legal origin characterized by a common law legal origin and high judicial efficiency. There are many studies focus on the association between legal origin and corporate governance; however, as we would say, the extant evidence is not sufficient to draw any opinion on the impact of IFRS or local GAAP on post-merger performance for bank industry. 
Some studies suggest that, for example, Christensen et al. (2013) find that regulate institutions and high quality financial reporting standards are reasonable proxies and benefits for capital markets. Florou and Pope (2012) find an increase in equity investment by investors in countries with strong legal origin after adoption of IFRS. Filip et al. (2015) suggest that financial reporting system is consistent across both common law and code law environments; their results are not affected by differential accounting standards, whereas findings are influence of the legal institution of a country on financial reporting.

Jaggi and Low (2000) show that firms from common law countries are associated with higher financial disclosures compared to firms from code law countries. Ball et al. (2000) and Carlin and Mayer (2003)'s findings suggest that common-law origin is positively associated with accounting standards and corporate governance. Boubakri et al. (2005) find that the effect of ownership concentration on firm performance is stronger in those countries and these results suggest that ownership concentration is a key mechanism of corporate governance. Bottazzi et al (2009) find that the investor's legal system is more important than that of the company in determining investor behavior. Accordingly, Beck et al. (2003) show that legal origin can influences financial development. This is consistent with Starks and Wei (2013) argues that we employ an indicator variable for whether the bank is domiciled in a country with common law legal origins.

Based on one of the important results of this literature is that common law countries provide the strongest legal protection to investors while code law countries provide the weakest (La Porta et al., 1998, 2000). Similarly, Jaggi and Low (2000) implied common law countries have higher levels of financial disclosure than code law countries. Nobes (1998) find that significant to the relationship between accounting standards, legal system and the predominant source of finance. Barniv et al. (2005) suggest common law countries have more effective corporate governance mechanisms as a higher quality financial reporting standards than code law countries. In contrast to, Wang and $\mathrm{Yu}$ (2015) find that a significantly negative relationship between stock price and the quality of financial reporting in countries with a common law and generally better shareholder protection.

Cross-border mergers and acquisitions (M\&As) have acknowledged significant consideration in the accounting and finance literature (Bris and Cabolis, 2008; Rossi and Volpin, 2004). The recent literature features the M\&As have the potential to show quality of investors protection (La Porta et al., 1998; Rossi and Volpin, 2004). Among the world, the legal origins and bank regulations play an important role in the corporate governance mechanism. More importantly, strong legal origin and strict regulations could allow different countries banks to operate effectively by undertaking M\&A between countries with different financial reporting systems. Once considering the differences between the legal origins and bank regulatory rules of different countries, this study shows that the legal origin and regulatory scope rule play a significant role (Shirasu, 2018) in the post-merger bank performance. 


\subsection{Hypotheses Development}

We conduct analysis in the setting of mandatory IFRS and local GAAP depend on legal system, using a banking sample of adopting countries as of the end of 2012. Our consistent results across these two different accounting settings seem to suggest that the information-improving role of high-quality accounting standards depends on a country's legal origin. To examine the evolution of the ownership structure according to the origin of commercial laws, we divide the sample into two groups such as common law countries and civil law countries. La Porta et al. (1998) suggest that common law countries provide better investor protection and high quality accounting system than code law countries. We except that common law countries provide better performance than code law countries, which may influence the post-performance under local GAAP.

Because IFRS are generally derived from financial accounting standards improved in common law countries, comparability is greater for common law firms. Moreover, accounting rules likely reflect the influence of a country's legal and institutional framework (Leuz et al., 2003). However, if it is accepted that IFRS represent a more uniform and less conservative set of standards than most local GAAP in the world, then common-law countries can be expected to show less divergence from IFRS. Mitton (2002) discovers that firms with higher disclosure quality and outside ownership concentration tend to have better performance over the financial crisis period. Ding et al. (2005) find that no significant relationship with legal origin and corporate governance mechanism. Barth et al. (2012) find that comparability is significantly greater for IFRS firms in countries with common law legal origin and with high enforcement. In contrast, Leuz et al. (2003) show that earnings management is negatively associated with the quality of minority shareholder rights and legal enforcement.

In much country's economy, the M\&A play a crucial role in special laws govern. Therefore, governments have developed M\&A laws in order to expand the states economies and enhance corporate performance, thereby maintaining proper competitive environments for improving corporate performance (Ciobanu, 2015). Marshall and Anderson (2009) suggest that target company announcement returns and takeover premiums are higher as regulation increase. Anderson et al. (2009)'s findings result show that in strong investor protection environments, target with lower debt level attract higher bids and that there is a negative relationship between a target's size and announcement return. This study aim is to reflect that the legal origin of a country can affected the characteristics of M\&As in terms of legal origin. The reason why we studied the impact of legal origin on the bank M\&A and corporate governance was to show that legal origin has an effect on the M\&A process both at the common law countries and code law countries. Ciobanu (2015) suggests that M\&A transaction is influenced not only by the legal origin, but also of the regulations governing the companies' activities. Accordingly, the legal origins also maintain that legal traditions are robustly linked to financial development. Thus, common law countries tend to be more economically developed with more 
sophisticated financial markets and development. Essentially, legal origin does not maintain that common law always produces the most economically efficient outcome (Fairfax, 2009). This leads to the following hypotheses H1.

H1: there are significant differences in the link between bidder bank's corporate governance mechanism and post-merger performance.

\section{METHODOLOGY AND DATA SOURCES}

\subsection{Data}

The data set is obtained by combining two sources: Thomson One Banker M\&A for data on the M\&A operations and Bankscope for balance sheet and income statement data of the banks involved in M\&A operations (Altunbaş and Marques, 2008). It comprises M\&A deals announced between 1/1/2002 and 31/12/2012 in which the acquirer is a EU banks and the target is a bank operating in any country of the world. A number of financial variables and ratios were sourced from North America (US and Canada) European Union (EU)-28 and Western Europe (Norway, Switzerland and Turkey) samples. The sample included listed bank companies. The sample period is made up of ten reporting periods of financial information prepared according to each country's own local GAAP or IFRS standards between 2003 and 2012. This period is chosen because it is the time period between approved of international accounting standards by the European Communicates was accepted (19 July 2002) and all the firms started to fulfil the requirements of this regulation 2005. More importantly, we consider the differences in the business cycle among countries and the fact that the post-mandatory adoption period (2005-2012) was heavily marked by the global financial crisis.

Our data cover registered M\&A that took place in the banking sector between 2003 and 2012. To be included in the sample, both the target and the bidder banks had to be independent commercial banks based in North America, European Union (EU)-28, and Western Europe at the time of the merger, and the bidder must not have been involved in any other merger in the 3 years prior to the merger. We will classify target firm as two groups, one is adopting IFRS and other adopt local GAAP. This paper analyzes the importance of two aspects of the legal origin as well as common law and code law in shaping bank merger firm's post-merger performance and accounting standards across the countries. To proxy for the impact of legal origin on corporate governance regulations in the bidder firm's postperformance around the announcement date of bank M\&A and target firms' countries construct a number of legal origin indexes. With the use of bank merger company from different countries, we create a corporate governance database comprising the main aspects and changes in corporate governance regulation (La Porta et al.,1998; Bris and Cabolis, 2008; Martynova and Renneboog, 2008) in North America, European Union and Western Europe countries since 2002. In our study, the classification of the legal origin as indicates a common law countries (United States, United Kingdom, 
Canada, Ireland) and code law countries (Norway, Switzerland, Turkey, Germany, Austria, Belgium, Bulgaria, Denmark, Estonia, Finland, France, Greece, Slovenia, Slovak Republic, Romania, San Marino, Spain, Sweden, Macedonia, Monaco, Netherland, Poland, Portugal, Hungary, Italy, Latvia, Liechtenstein, Lithuania, Luxembourg) are based on La Porta et al. (1998), Leuz et al. (2003) and Hope (2003a).

Table 1. Sample Data

\begin{tabular}{|c|c|c|c|}
\hline & Country & Freq. & Percent \\
\hline \multirow{4}{*}{} & AT & 8 & 3,25 \\
\cline { 2 - 4 } & BG & 2 & 0,81 \\
\cline { 2 - 4 } & CH & 14 & 5,69 \\
\cline { 2 - 4 } & DE & 19 & 7,72 \\
\cline { 2 - 4 } & DK & 5 & 2,03 \\
\cline { 2 - 4 } & ES & 16 & 6,50 \\
\cline { 2 - 4 } & FR & 1 & 0,41 \\
\cline { 2 - 4 } & GB & 5 & 2,03 \\
\cline { 2 - 4 } & GR & 1 & 0,41 \\
\cline { 2 - 4 } & HU & 1 & 0,41 \\
\cline { 2 - 4 } & IT & 15 & 6,10 \\
\cline { 2 - 4 } & LT & 2 & 0,81 \\
\cline { 2 - 4 } & LU & 3 & 1,22 \\
\cline { 2 - 4 } & NO & 5 & 2,03 \\
\cline { 2 - 4 } & PL & 3 & 1,22 \\
\cline { 2 - 4 } & PT & 3 & 1,22 \\
\cline { 2 - 4 } & RO & 7 & 2,85 \\
\cline { 2 - 4 } & SE & 6 & 2,44 \\
\cline { 2 - 4 } & TR & 3 & 1,22 \\
\cline { 2 - 4 } & Total & $\mathbf{1 1 9}$ & $\mathbf{4 8 , 3 8}$ \\
\hline & US & 125 & 50,81 \\
\cline { 2 - 4 } & IE & 2 & 0,81 \\
\cline { 2 - 4 } & Total & $\mathbf{1 2 7}$ & $\mathbf{5 1 , 6 2}$ \\
\hline G.Total & 246 & 100,00 \\
\hline
\end{tabular}

Table 1 shows descriptive statistics regarding common law and code law countries in our sample period. The 246 banks are distributed across the following two legal systems: 51,62\% of the firms come from common law, and 48,38\% from the code law countries.

\subsection{Methodology}

To test the relationship between corporate governance practices and post-merger bank performance, we use a firm collected Linear regression model (Zakaria et al., 2017), which is as follows:

Post-merger financial performance $=\beta 0+$ B1 AccountingStandards At $_{i t}+\beta 2$ LegalOrigin $_{\text {it }}+$ B3AuditFees $_{\text {it }}+$ B4size $_{\text {it }+}$ eit (1)

Dependent variables are the bank-specific financial statements variables, including capital structure, etait, assets structure, nltait, funding structure, Irlit, cost-efficiency, cirit, income structure, niexpait, and profitability, obstait. The financial performance indicators, as covers dependent variables are detailed under this section, that we employ are traditional indicators of bank performance with 
respect to capital structure, asset and funding structures, cost efficiency, income structure and profitability.

The independent variable for all of the regressions is the corporate governance practices during the post-merger period. We use three alternative proxies for the measure of corporate governance practices in the bidder and target countries. Our first proxy is an important aspect of investor confidence in a financial market is the quality of disclosure to the investors. To measure investor confidence, we use an estimate of the quality of country`s accounting standards, obtained from La Porta et al. (1998). This measurement is constructed based on the examination of company reports from different countries. The higher the index, the better are the accounting standards in that country (Starks and Wei, 2013). This variable affects M\&A activity because good disclosure is a necessary condition for identifying potential targets. Accounting standards also reflect corporate governance, because they reduce the scope for expropriation by making corporate accounts more transparent. Rossi and Volpin (2004) find that the volume of M\&A activity is significantly larger in countries with better accounting standards and stronger shareholder protection.

Our second proxy is the legal origin of the bidder banks' home country. Legal systems, cultures and polities are important in explaining the disparity of investor protection and market capitalization around the world. Corporate governance and investor protection are key drivers of market development (Matoussi and Jardak, 2012). By comparing legal rules across the countries, we showed that legal rules from the different traditions differ in content as well as in the history of their adoption. We also showed that richer countries enforce laws better than poorer countries, but, controlling for per capita income, code law countries have the lowest quality of law enforcement as well (La Porta et al., 1997; La Porta et al., 1998).

Our third proxy, the firms' audit fees, is an important measure of corporate governance for two reasons (Rustam et al., 2013). First, auditors are an integral part of corporate governance and can potentially work with other governance actors to improve the quality of the financial reporting process (Cohen et al., 2002). Second, audit fees paid to auditors as a measure of corporate governance result in an effective loss of profit to the shareholders, and a major shareholder will also increase the demand for external audit services to reduce risk. Therefore, the exercise of independent corporate governance can lead to an increase in the demand for external auditing and thus an increase in audit fees. Hay et al. (2008) find that measures of corporate governance and concentration of ownership are all positively related to audit fees.

In addition, as control variables, we include the log of firm size in the regressions. Thus, each variables descriptions are listed in Table 2. 
Table 2. Bank Financial Performance Indicators

\begin{tabular}{ll}
\hline Variable & Description \\
\hline Return on Assets (roa) & Earnings after tax divided by total assets and multiplied by 100 \\
Equity to asset (eta) & $\begin{array}{l}\text { Equity to total assets at given year. } \\
\text { The ratio of operating expenses to total operating income at } \\
\text { given year. }\end{array}$ \\
Cost-Efficiency (cir) & $\begin{array}{l}\text { Loan loss reserve to gross loans at given year. } \\
\text { Loan loss reserve (llrl) }\end{array}$ \\
$\begin{array}{l}\text { Net loans (nlta) } \\
\text { Non-interest } \\
\text { (niexpa) }\end{array}$ & $\begin{array}{l}\text { Non-interest expense to average total assets at given year. } \\
\text { Off balance sheet (obsta) }\end{array}$ \\
Firm Size (size ) & Off balance sheet total asset at given year. \\
\hline
\end{tabular}

Source: Composed by author.

Prior research indicates that audit committee independence is positively related to effective oversight of the financial reporting process. Several prior studies have found significant positive relationships between audit fees, board independence, audit committees and external auditing (Engel $e t$ al., 2010; Goodwin et al., 2009). These results show the relationship between corporate governance mechanisms and various aspects of the financial reporting and audit processes. For example, Chahine and Flatothchev (2011), Barako et al. (2006), and Tsui et al. (2001) find that audit committees are a significantly negatively associated with the extent of voluntary disclosure. Rainsbury et al. (2009) show no significant association between the quality of an audit committee and quality of financial reporting.

We find that the important enforcement proxy such as audit fees add to the more general proxy in that they are always negatively and significantly associated with corporate governance measurement and with disagreement between legal origin in models where a more general proxy is also included. Brown et al. (2014) imply that auditors will provide compliance with accounting standards. Hope (2003b) suggests high fees do not necessarily correlate with effective enforcement. Audit fees are thus higher when financial reporting non-compliance is greater, implying the level of audit fees is not a suitable proxy for enforcement. Our result is consistent with the notion that audit fees are negatively and significantly with corporate governance enforcement in bank industry.

Next, in our study was used to $\mathrm{Z}$ score criterion as a reliable model for determining banks' distress risk which was merged bank in bank industry for determination of if these banks were financially successful or not. We were determined to examine the banks' financial success for post-performance measurement such as asset quality (size, eta, llrl and nlta), cost efficiency (cir and niexpa) and profitability (obsta). Z score in accuracy of the developed bankruptcy model was calculated below for bank industry (Chiaramonte et al., 2015).

\section{$\mathrm{Z}=($ Roa + Equity $) /$ Assets $) /$ St dev. of Roa (2)}

We explore that the mean $\mathrm{Z}$ score is significantly high in the merger banks, which means safe zone and no bankruptcy because of $\mathrm{Z}$ scores of discriminations higher than 2.9. 
Table 3 shows descriptive statistics concerning corporate governance, legal origin and IFRS adoption in bank mergers during the post-merger performance in our sample period for the 246 banks in the study sample. The 246 banks are distributed across the following three geographical regions: $51 \%$ of the firms come from North America, 9\% from Western Europe, and 40\% from the European Union. Interestingly, this diversification involves countries with different levels of development and different legal and institutional environments. Likewise, the sample countries encompass two legal contexts: 54\% of the firms come from common law countries and 39\% from code law countries. We also consider the various components of the index, as well as accounting standards, other audit expenses and differences in firm size, eta, Ilrl, niexpa, obsta and cir as robustness checks. Table 3 also shows that the sample is diversified across accounting standards with $15 \%$ in the merged-IFRS group, $22 \%$ in the merged-local GAAP group and 63\% in non-merger banks from different countries.

Table 3. Descriptive Statistics During Post-Merger Performance Period

\begin{tabular}{lllllll}
\hline Variables & $\mathbf{N}$ & Mean & $\mathbf{p 5 0}$ & $\begin{array}{l}\text { Standard } \\
\text { Deviation }\end{array}$ & Minimum & Maximum \\
\hline Zscorel & 246 & 25.99 & 20.32 & 21.18 & 97.53 & 0.60 \\
Size & 246 & 16.55 & 16.22 & 2.18 & 11.24 & 21.84 \\
Eta & 246 & 9.01 & 9.11 & 3.85 & 1.45 & 24.86 \\
Nlta & 246 & 59.70 & 63.95 & 18.27 & 5.56 & 92.38 \\
Llrl & 246 & 2.15 & 1.69 & 1.73 & 0.08 & 15.32 \\
Cir & 246 & 66.37 & 64.98 & 25.78 & 24.97 & 353.55 \\
Niexpa & 246 & 3.14 & 2.98 & 1.67 & 0.64 & 12.79 \\
Obsta & 246 & 19.93 & 13.58 & 30.57 & 0.03 & 275.97 \\
Attfrs & 246 & 0.15 & 0.00 & 0.36 & 0.00 & 1.00 \\
Atgaap & 246 & 0.22 & 0.00 & 0.41 & 0.00 & 1.00 \\
Comlaw & 246 & 0.54 & 1.00 & 0.50 & 0.00 & 1.00 \\
Codlaw & 246 & 0.39 & 0.00 & 0.49 & 0.00 & 1.00 \\
Feem & 105 & 5.35 & 1.52 & 9.67 & 0.01 & 45.00 \\
\hline
\end{tabular}

Furthermore, we explore the fact that the mean $\mathrm{Z}$ score is significantly high in merger banks, which indicates the presence of a safe zone and the absence of bankruptcy when the $\mathrm{Z}$ scores is higher than 2.9. In addition, capital structure is better with $9.01 \%$. Finally, in general, the bidder banks are larger than the target institutions. Our findings indicate that while the mean of Ilrl and niexpa is slightly higher at 2.15 and 3.14, respectively, the business diversification and cir variables are concurrently significant at normal and expected levels.

\section{RESULTS}

Table 4 provides the impacts of corporate governance practices on the post-merger performance in our sample. Panel A indicates whether the country has better or worse corporate governance for postmerger performance under IFRS or local GAAP. Our findings evidence that on all performance measures, IFRS groups provide merged-banks with smaller access to capital structure than local GAAP groups. IFRS groups have the average ratio of eta to -0.484 is significant at $5 \%$ level, compared to 0,583 is significant at $1 \%$ level for the local GAAP groups. The profitability is significant at $10 \%$ above 
IFRS groups average in this sample, which is not entirely surprising given that it is growing much slower than local GAAP merged banks, but no significant. During this period, we look at, while IFRS groups averaged -0.088 ratio of off balance sheet total assets (obsta) as a business diversification is significant difference at $1 \%$ level, -0.104 of an obsta for the local GAAP groups.

Table 4. Impacts of Corporate Governance Practices During the Post-Merger Performance

\begin{tabular}{|c|c|c|c|c|c|c|c|c|c|c|c|}
\hline & Dependent Variable & $\begin{array}{l}\text { Panel A } \\
\text { atıfrs }\end{array}$ & & atgaap & & $\begin{array}{l}\text { anel B } \\
\text { comlaw }\end{array}$ & & codlaw & & $\begin{array}{l}\text { Panel C } \\
\text { feem }\end{array}$ & \\
\hline & Size L1 & $\begin{array}{l}1.060 \\
(0.672) \\
\end{array}$ & & $\begin{array}{l}1.824 \\
(0.544) \\
\end{array}$ & $* * *$ & $\begin{array}{l}1.558 \\
(0.640) \\
\end{array}$ & $* * *$ & $\begin{array}{l}1.694 \\
(0.660) \\
\end{array}$ & $* *$ & $\begin{array}{l}0.037 \\
(1.086) \\
\end{array}$ & \\
\hline 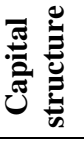 & eta $\mathrm{L1}$ & $\begin{array}{l}-0.484 \\
(0.215)\end{array}$ & $* *$ & $\begin{array}{l}-0.583 \\
(0.210)\end{array}$ & $* * *$ & $\begin{array}{l}-0.582 \\
(0.244)\end{array}$ & $* * *$ & $\begin{array}{l}-0.636 \\
(0.240)\end{array}$ & $* *$ & $\begin{array}{l}-1.177 \\
(0.460)\end{array}$ & $* *$ \\
\hline 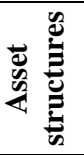 & $\begin{array}{l}\text { nlta L1 } \\
\text { llrl L1 }\end{array}$ & $\begin{array}{l}-0.021 \\
(0.105) \\
2.099 \\
(0.792)\end{array}$ & $* *$ & $\begin{array}{l}-0.022 \\
(0.116) \\
2.117 \\
(0.872)\end{array}$ & $* *$ & $\begin{array}{l}-0.025 \\
(0.107) \\
1.718 \\
(0.656)\end{array}$ & $* * *$ & $\begin{array}{l}-0.025 \\
(0.110) \\
2.151 \\
(0.753)\end{array}$ & $* * *$ & $\begin{array}{l}0.074 \\
(0.100) \\
0.580 \\
(1.289)\end{array}$ & \\
\hline نे & $\operatorname{cir} \mathrm{L1}$ & $\begin{array}{l}0.053 \\
(0.036)\end{array}$ & & $\begin{array}{l}0.068 \\
(0.037)\end{array}$ & $* * *$ & $\begin{array}{l}0.062 \\
(0.031)\end{array}$ & $* * *$ & $\begin{array}{l}0.055 \\
(0.032)\end{array}$ & $*$ & $\begin{array}{l}0.026 \\
(0.091)\end{array}$ & \\
\hline 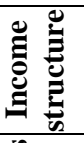 & niexpa L1 & $\begin{array}{l}2.147 \\
(1.177)\end{array}$ & $*$ & $\begin{array}{l}2.040 \\
(1.324)\end{array}$ & & $\begin{array}{l}2.266 \\
(1.170)\end{array}$ & $* * *$ & $\begin{array}{l}2.263 \\
(1.159)\end{array}$ & $* * *$ & $\begin{array}{l}0.358 \\
(1.455)\end{array}$ & \\
\hline 离 & obsta L1 & $\begin{array}{l}-0.088 \\
(0.031)\end{array}$ & $* * *$ & $\begin{array}{l}-0.104 \\
(0.031)\end{array}$ & $* * *$ & $\begin{array}{l}-0.094 \\
(0.036)\end{array}$ & $* *$ & $\begin{array}{l}-0.102 \\
(0.034)\end{array}$ & $* * *$ & $\begin{array}{l}-0.182 \\
(0.075)\end{array}$ & $* *$ \\
\hline & _cons & $\begin{array}{l}-52.782 \\
(13.109) \\
\end{array}$ & & $\begin{array}{l}-61.720 \\
(10.753) \\
\end{array}$ & & $\begin{array}{l}-55.069 \\
(11.478) \\
\end{array}$ & & $\begin{array}{l}-61.087 \\
(10.822) \\
\end{array}$ & & $\begin{array}{l}-14.230 \\
(27.240) \\
\end{array}$ & \\
\hline & No. of observations & 246 & & 246 & & 246 & & 246 & & 105 & \\
\hline & $\mathbf{R 2}$ & 0.1630 & & 0.1387 & & 0.1417 & & 0.1351 & & 0.2348 & \\
\hline & $\mathbf{F}$ & 39.61 & & 0.00 & & 8.33 & & 43.90 & & 9.01 & \\
\hline & Prop $>$ F & 0.0000 & & 0.0000 & & 0.0000 & & 0.0000 & & 0.0000 & \\
\hline & Root MSE & 20.091 & & 20.382 & & 20.345 & & 20.423 & & 16.591 & \\
\hline
\end{tabular}

Note: $*, * *, * * *$ denote significance at the $10 \%, 5 \%$, and $1 \%$ levels, respectively. The standard errors of the coefficients are in parenthesis. Corporate governance practices stand for proxies including legal origin, accounting standards and firms' audit fees.

More importantly, during this period, on all the post-performance measures such as assets quality, cost efficiency and profitability, the differences in coefficients between the IFRS groups and local GAAP groups are statistically significant except for niexpa only. Furthermore, our result finds that local GAAP groups are higher llrl than merged-IFRS groups. These factors decrease post-merger performance. Finally, as Panel A illustrates, because of higher risk in the post-merger performance for local GAAP groups, we find evidence that the target takeover premium should be decreasing in the quality of the bidder's corporate governance, which depends on the country's account standards. As a result, we would say that post-merger performance is significantly larger in countries with better IFRS groups' banks and local GAAP groups can weaker corporate governance than IFRS groups. According to Panel A, nlta no contributed post merger financial performance. 
Panel B shows the aggregate data used in this study, with 21 countries comparisons across legal origins. Explicit contracts and extensive rights protect investors, which in turn requires a wellfunctioning legal system. In such a system, corporate financial reporting and disclosure is crucial to resolve information asymmetries among firms and investors (Leuz, 2010). Legal origin is an important conditioning variable for the role of culture and perhaps the most important from an accounting research perspective is the difference in agency problems. Although legal origin is a key determinant of disclosure levels, Hope (2003a) find that its importance decreases with the richness of a firm's information environment. Moreover, the governance transparency factor is primarily related to a country's legal origin. Bushman et al. (2004) findings document that governance transparency is higher in countries with a legal origin characterized by a common law legal origin and high judicial efficiency. Ciobanu (2015) suggests that M\&A transaction is influenced not only by the legal origin, but also of the regulations governing the companies' activities.

Our findings are much interesting results jump out. First, on all performance measures, common law countries provide merged-banks with smaller access to capital structure than code law countries. Common law countries have the average ratio of eta to -0.582 is significant at $5 \%$ level, compared to 0.636 is significant for the code law countries. The profitability, incidentally, is above common law average in this sample, which is not entirely surprising given that it is growing much slower than others. Second, during this period we look at, while common law countries averaged -0.094 ratio of obsta is significant difference at $5 \%$ level, -0.102 of an obsta for the code law. More importantly, during this period, on all the post-performance measures such as assets quality, cost efficiency and profitability, the differences in coefficients between the common law countries and the code origin are statistically significant except for cir only. Furthermore, our result find that code law countries are higher llrl than common law countries. These factors decrease post-merger performance. Finally, as Panel B illustrates, because of higher risk in the post-merger performance for code law countries, we find evidence that the target takeover premium should be decreasing in the quality of the bidder's corporate governance, which depends on the country's legal origin. Accordingly, our findings show that legal origin affects the efficiencies of corporate governance and ultimately corporate profitability under common law system is increasing the level of bank post-merger performance than code law ones. As a result, we would say that code law countries can weaker corporate governance than common law countries.

Our results are consistent with previous studies conducted on by Starks and Wei (2013) find that legal origin is increasing with better corporate governance practices. Matoussi and Jardak (2012) findings show that the legal origin is a robust factor with both direct and indirect effects on stock market capitalization. Beck et al. (2003) provide that the exogenous component of the political channel does not explain cross-country variation in financial development. Chen et al. (2009) find that institutional investors are willing to pay a higher premium for shares in firms with good corporate governance, especially when the firms are in countries where the legal protection of investors is weak. La Porta et 
al. (1997) find that code law countries have both the weakest investor protections and the least developed capital markets, especially as compared to common law countries.

Prior research indicates that audit committee independence is positively related to effective oversight of the financial reporting process. Several prior studies have found significant positive relationships between audit fees, board independence, audit committees and external auditing (Engel et al., 2010; Goodwin et al., 2009). These results show the relationship between corporate governance mechanisms and various aspects of the financial reporting and audit processes. Lin and Hwang (2010), however, find that for corporate governance, the independence and expertise of the board of directors are negatively related to earnings management. Chahine and Flatothchev (2011), Barako et al. (2006) and Tsui et al. (2001) find that audit committees are a significantly negatively associated with the extent of voluntary disclosure. Naiker and Sharma (2009) indicate that affiliated and unaffiliated audit committees are negatively associated with the incidence of internal control deficiencies. Anderson et al. (2004) find that independent audit committees are associated with a significantly lower cost of debt financing. Rainsbury et al. (2009) show no significant association between the quality of an audit committee and quality of financial reporting. Our results are consistent with previous studies conducted on by Rainsbury et al. (20009) find that no significant association between the audit fees and quality of financial reporting, except for eta and obsta, but negatively significant effect at the 5\% level.

Panel $\mathrm{C}$ indicates whether the country has better or worse corporate governance in terms of audit expenses, including expenses for audit advisors, in the post-merger performance period. Our findings show that on all performance measures, fee proxies provide merged banks with the least access to capital structures compared to both account standards and legal origin proxies, with the exception of nlta. Our results show that the average eta ratio of -1.117 is significant at the $5 \%$ level. During the period under study, obsta as a measure of business diversification shows a significant difference at the $5 \%$ level. In addition, our results provide evidence that all performance measures are significant with the exception of eta and obsta. We would therefore argue that there are no significant associations between fee indicators and corporate governance other than eta and obsta.

As a result, according to Table 4, post-merger performance is negatively influenced to corporate governance practices with eta and obsta, while positively association such as size, llrt, cir and niexpa. However, our results suggest that nlta no contributed to corporate governance practices.

\section{CONCLUSION}

We consider the impact of corporate governance on bank performance induced by mergers. For bank industries in different countries over the period 2003-2012, we construct measures of the impact of legal origin on corporate governance in that industry. We also show that a strong rule of law origin and security owner protection mechanisms in the acquiring firm country act as a substitute contracting 
mechanism for mitigating post-performance. Whereas all performance measures, common law countries provide merged-banks with smaller access to capital structure than code law countries; code law countries can weaker corporate governance than common law countries. Overall, our findings suggest that the motivations of bidder to bank post-performance is influenced by legal origin differences in the target home country as corporate governance standards. Therefore, legal system differences could be important to a successful bank M\&A under the accounting standards.

We suggest that post-merger performance is significantly larger in countries with better IFRS groups' banks and local GAAP groups can weaker corporate governance than IFRS groups. More importantly, we find that common law accounting standards give greater information related to bank performance in code law countries are determined primarily in the accounting disclosure. Our result shows that IFRS in a code law country that does not suppress investor protection which may influence the post-merger performance, is determined by legal origin, so that technical differences between IFRS and local GAAP standards are an important key factor. Our results are consistent with previous studies by Ciobanu (2015) find that M\&A activities is influenced both the legal origin and accounting regulations. In addition, our results suggest that no significant association between the audit fees and quality of financial reporting, which is consistent with previous studies by Rainsbury et al. (20009), except for eta and obsta, but negatively significant effect.

The legal origin and financial reporting regulations, plays an crucial important role in postmerger bank performance. Therefore, M\&A activities between countries with different economic regimes could allow multinational banks to operate effectively by undertaking corporate governance practices. The recent study could increasingly exploring diversification into foreign investments might offer interesting opportunities in studying banks' acquisitions, namely global financial crisis.

\section{Acknowledgements}

The author appreciates the generous research support of the Bangor Business School at Bangor University. The author thanks Prof. Yener Altunbas for helpful comments.

\section{REFERENCES}

Allen, F., Qian, J. and Qian, M. (2005). Law, finance, and economic growth in China. Journal of Financial Economics, 77, 57-116.

Altunbas, Y. and Marqués, D. (2008). Mergers and acquisitions and bank performance in Europe: The role of strategic similarities. Journal of Economics and Business, 60, 204222.

Anderson, R., Mansi, S. and Reeb, D. (2004). Board characteristics, accounting report integrity, and the cost of debt. Journal of Accounting and Economics, 37(3), 315-342.

Anderson, H.D., Marshall, B.R. and Wales, R. (2009). What is the relationship between investor protection legislation and target takeover returns? Evidence from Europe. Journal of Multinational Financial Management, 19, 291-305. 
Ball, R., Kothari, S. and Robin, A. (2000). The effect of international institutional factors on properties of accounting earnings. Journal of Accounting and Economics, 29, 1-51.

Ball, R., Robin, A. and Wu, J.S. (2003). Incentives versus standards: properties of accounting income in four East Asian countries. Journal of Accounting and Economics, 36, 235270.

Barako, D.G., Hancock, P. and Izan, H.Y. (2006). Factors influencing voluntary corporate disclosure by Kenyan companies. Corporate Governance: An International Review,14(2), 107-125.

Barniv, R., Myring, M. and Thomas, W. (2005). The Association Between the Legal and Financial Reporting Environments and Forecast Performance of Individual Analysts. Contemporary Accounting Research, Vol.22, No.4, 727-758.

Barth, M.E., Landsman, W.R., Lang, M. and Williams, C. (2012). Are IFRS-based and US GAAP-based Accounting Amounts Comparable? Journal of Accounting and Economics, 54(19, 68-93.

Beck, T., Demirgüç-Kunt, A. and Levine, R. (2003). Law and finance: why does legal origin matter?. Journal of Comparative Economics, 31, 653-675.

Boubakri, N., Cosset, J-C. and Guedhami, O. (2005). Post-privatization corporate governance:The role of ownership structure and investor protection. Journal of Financial Economics, 76, 369-399.

Bottazzi, L., Da Rin, M. and Hellmann, T. (2009). What is the role of legal systems in financial intermediation? Theory and evidence. J. Financial Intermediation, 18, 559-598.

Bris, A. and Cabolis, C. (2008). The value of investor protection: Firm evidence from crossborder mergers. Review of Financial Studies, 21, 605-648.

Brown, P., Preiato, J. and Tarca, A. (2014). Measuring Country Differences in Enforcement of Accounting Standards: An Audit and Enforcement Proxy. Journal of Business Finance \& Accounting, 41(1-2), 1-52.

Bushman, R.M., Piotroski, J.D., and Smith, A.J. (2004). What determines corporate transparency?. Journal of Accounting Research, 42(29), 207-252.

Carlin, W. and Mayer, C. (2003). Finance, investment, and growth. Journal of Financial Economics, 69, 191-226.

Chahine S. and Filatotchev, I. (2011). The effects of corporate governance and audit and nonaudit fees on IPO value. The British Accounting Review, 43, 155-172.

Chen, K.C.W., Chen, Z. and Wei, K.C.J. (2009). Legal protection of investors, corporate governance, and the cost of equity capital. Journal of Corporate Finance, 15, 273-289.

Chiaramonte, L., Croci, E. and Poli, F. (2015). Should we trust the Z-score? Evidence from the European Banking Industry. Global Finance Journal, 28, 111-131.

Christensen, H., Hail, L. and Leuz, C. (2013). Mandatory IFRS reporting and changes in enforcement. Journal of Accounting and Economics, 56, 147-177.

Ciobanu, R. (2015). Mergers and acquisitions: does the legal origin matter? Procedia Economics and Finance, 32, 1236-47.

Cohen, J., Moorthy, G. and Wright, A. (2002). Corporate governance and the audit process. Contemporary Accounting Research, 19(4), 573-594.

Choi, J. H. and Wong, T. J. (2007). Auditors' governance functions and legal environments: An international investigation. Contemporary Accounting Research, 24, 13-46. 
Daske, H., Hail, L., Leuz, C. and Verdi, R. (2008). Mandatory IFRS Reporting Around the World: Early Evidence on the Economic Consequences. Journal of Accounting Research, 46(5), 1085-1142.

DeFond, M. and Zhang, J. (2014). A review of archival auditing research. Journal of Accounting and Economics, 58, 275-326.

Ding, Y., Jeanjean, T. and Stolowy, H. (2005). Why do national GAAP differ from IAS? The role of culture. The International Journal of Accounting, 40, 325-350.

Drever, M., Stanton, P. and McGowan, S. (2007). Contemporary Issues in Accounting, Australia: John Wiley\&Sons Australia, Ltd.

Engel, E., Hayes, R.M. and Wang, X. (2010). Audit committee compensation and the demand for monitoring of the financial reporting process. Journal of Accounting and Economics, $49,136-154$.

Fairfax, L.M. (2009). The Legal Origins Theory in Crisis", BYU L. Rev. 1571 (2009). Available at: https://digitalcommons.law.byu.edu/lawreview/vol2009/iss6/5

Filip, A., Labelle, R. and Rousseau, S. (2015). Legal Regime and Financial Reporting Quality. Contemporary Accounting Research, 32(1), 280-307.

Florou, A. and Pope, P. (2012). Mandatory IFRS Adoption and Investor Asset Allocation Decisions. The Accounting Review, Vol.87(6), 1993-2025.

Goodwin, J., Karman, A. and Heanly, R. (2009). Corporate Governance and the Prediction of the Impact of AIFRS Adoption. Abacus, 45, 124-145.

Hay, D., Knechel, W.R. and Ling, H. (2008). Evidence on the impact of internal control and corporate governance on audit fees. International Journal of Auditing, 12(1), 9-24.

Hitz, J-M., Ernstberger, J. and Stich, M. (2012). Enforcement of Accounting Standards in Europepp. Capital-Market-Based Evidence for the Two-Tier Mechanism in Germany. European Accounting Review, 21(2), 253-281.

Hope, O-K. (2003a). Firm-level disclosures and the relative roles of culture and legal origin. Journal of International Financial Management and Accounting, 14(3), 218-248.

Hope, O.-K. (2003b). Disclosure Practices, Enforcement of Accounting Standards, and Analysts' Forecast Accuracy: An International Study. Journal of Accounting Research, 41(2), 235-272.

Jaggi, B. and P. Low. (2000). Impact of Culture, Market Forces, and Legal System on Financial Disclosures. The International Journal of Accounting, Vol.35 No.4, 495-519.

Kuo, N-T. and Lee, C-F. (2018). Investor legal protection, capitalized development costs, and audit fees: A cross-country analysis. Journal Int Financ Manage Account.; 29, 57-82.

La Porta, R., Lopez-de-Silanes, F., Shleifer, A. and Vishny, R. (1998). Law and Finance. Journal of Political Economy, 106(6), 1113-1147.

La Porta, R., Lopez-de-Silanes, F., Shleifer, A. and Vishny, R.W. (1997). Legal Determinants of External Finance. The Journal of Finance, 52(3), 1131-1150.

La Porta, R., Lopez-de-Slanes, F., Shleifer, A. and Vishny, R. (2000). Investor Protection and Corporate Governance. Journal of Financial Economics, 58, 3-27.

La Porta, R, F. Lopez-de-Silanes, Shleifer, A. and Vishny, R. (2006). What Works in Securities Laws?. The Journal of Finance, 61(1), 1-32.

La Porta, R, Lopez-De-Silanes, F. and Shleifer, A. (2008). The economic consequences of legal origins. Journal of Economic Literature, 46, 285-332. 
Leuz, C., Nanda, D. and Wysocki, P.D. (2003). Earnings management and investor protection: an international comparision. Journal of Financial Economics, 69, 505-527.

Leuz, C. (2010). Different approaches to corporate reporting regulation: how jurisdictions differ and why. Accounting and Business Research, 40(3), 229-256.

Marshall, B.R. and Anderson, H.D. (2009). Regulation and target takeover returns: Is there a link?. Pacific-Basin Finance Journal, 17, 395-412.

Martynova, M. and Renneboog, L. (2008). Spillover of corporate governance standards in crossborder mergers and acquisitions. Journal of corporate finance, 14, 200-223.

Matoussi, H. and Jardak, M.K. (2012). International Corporate Governance and Finance: Legal, Cultural and Political Explanations. The International Journal of Accounting, 47, 1-43.

Mitton, T. (2002). A cross-firm analysis of the impact of corporate governance on the East Asian financial crisis. J. Financ. Econ. 64(2), 215-241.

Munisi, G. and Randøy, T. (2013). Corporate governance and company performance across Sub-Saharan African countries. Journal of Economics and Business, http://dx.doi.org/ 10.1016/j. jeconbus.2013.08.003.

Naiker, V. and Sharma, D.S. (2009). Former audit partners on the audit committee and internal control deficiencies. The Accounting Review, 84, 559-587.

Nobes, C. (1998). Towards a General Model of the Reasons for International Differences in Financial Reporting. Abacus, 34(2), 162-87.

Pope, P. and McLeay, S. (2011). The European IFRS Experiment: Objectives, Research Challenges and Some Early Evidence. Accounting and Business Research, 41(3), 23366.

Preiato, J., Brown, P. and Tarca, A. (2015). A Comparison of Between-Country Measures of Legal Setting and Enforcement of Accounting Standards. Journal of Business Finance and Accounting, 42(1-2), 1-50.

Rainsbury, E., Braudbury, M. and Cahan, S.F. (2009). The impact of audit committee quality on financial reporting quality and audit fees. Journal of Contemporary Accounting and Economics, 5, 20-33.

Rossi, S. and Volpin, P.F. (2004). Cross-country determinants of mergers and acquisitions. Journal of Financial Economics, 74, 277-304.

Rustam, S., Rashid, K. and Zaman, K. (2013). The relationship between audit committes, compensation incentives and corporate audit fees in Pakistan. Economic Modelling, 31, 697-716.

Shirasu, Y. (2018). Long-term strategic effects of mergers and acquisitions in Asia-Pacific banks. Finance Research Letters, 24, 73-80.

Starks, L.T. and Wei, K.D. (2013). Cross-Border Mergers and Differences in Corporate Governance. International Review of Finance 13(3), 265-297.

Tsui, J.S.L., Jaggi, B. and Gul, F.A. (2001). CEO domination, discretionary accruals and audit fees. Journal of Accounting, Auditing and Finance, 16(3), 189-207.

Wang, J.W. and Yu, W.W. (2015). The Information Content of Stock Prices, Legal Environments, and Accounting Standards: International Evidence. European Accounting Review, 24(3), 471-493.

Zakaria, R., Fernandez, W.D. and Schneper, W.D. (2017). Resource availability, international acquisition experience, and cross-border M\&A target search: A behavioral approach. Multinational Business Review, 25(3), 185-205. 